\title{
The Influence of Emotional and Spiritual Intelligence of Educator towards Learning Quality Improvement
}

\author{
Abdul Halik \\ Institut Agama Islam Negeri Parepare \\ abdulhaliknas@gmail.com
}

\author{
Suredah \\ Muhammadiyah University of Parepare \\ hjsuredah@gmail.com
}

\author{
Ahdar \\ Institut Agama Islam Negeri Parepare \\ ahdar.m0123@gmailcom
}

\begin{abstract}
Learning is crucial and contributes to the quality of education. The quality of learning process implicates the quality of education. The quality of teaching process in schools is played by a teacher. Excellent teachers are the ones having the emotional and spiritual intelligence when teaching in class. Also, it is highly required that they keep motivated to learn from their students. The study is aimed to describe the emotional intelligence that can create interaction between creative and conducive learning, and increase students' confidence. In addition, it will highlight spiritual intelligence that can improve the teachers' and students' self-awareness. They will be aware that learning is meaningful activities shaping the future. As a result, a teacher has emotional and spiritual intelligence affecting the students' transformation to create learning which is conducive, creative, innovative, effective, fun, and humanised. This study was carried out using mixed methods, implementing quantitative and qualitative approaches.
\end{abstract}

Keywords: Quality, Learning, Emotional, Intellectual, Spiritual, Intelligence

\section{INTRODUCTION}

If the world of education in a higher education is merely memorization oriented and focuses on cognitive aspects, the learners are probably able to develop their academically, but they may not ready to be independence [1]. Whereas secondary schools have a crucial role to provide the foundations for development of students attitudes and personalities. The education process should be more directed at the learners development in term of physical, psycological and religious potential [2].

Education is not just to learn scientific theory to develop Intelligence Quotient (IQ). Education should also cover core values, such as Spiritual Quotient (SQ), which should be developed in the daily life with a concrete objective of Emotional Quetient (EQ) [3]. Dani Ronnie (2006) said the emotional intelligence is simply the sensitivity reorganization and self-awareness, empathy and the sensitivity in managing these feelings then it becomes the framework for behaving, socializing or making the right decisions. Furthermore, Daniel Goleman (1997) added that the emotional intelligence is the ability of self-motivated and to deal with frustration, control impulse, and not exaggerate pleasure, regulate mood and keep stress burden not crippled thinking ability [4].

Emotional intelligence is the ability to feel conscience. It is the voice of the heart that should be the center of the principle that can provide security, guidance, strength, and wisdom. Furthermore, Ari Ginanjar (2000) convinced the research has proven that the emotional intelligence has more essential role compared with intellectual intelligence, like brain intelligence, for life success. The emotional intelligence can lead someone to gain the top achievement. It is important to realize that the interaction of learning occurs during this time. Overemphasizing the importance of academic value (IQ) rarely found the role of educators in developing the interaction of learning by developing patterns of integrity, honesty, commitment, vision, creativity, mental resilience, wisdom, , trust and selfmastery characterizing emotional intelligence [5], [6].

The spiritual Quotient (SQ) is the ability to provide spiritual meaning of thoughts, behaviors and activities that are able to synergize the three intelligences (IQ, EQ, and SQ) in a comprehensive way. The educator with spiritual intelligence is able to give meaning to each activity with pure thoughts "for the sake of God" $\mathrm{He}$ Who will provide devotion [7], [8],[9].

An excellent school is the one which is effective and efficient by promising the best graduates, having competitive and comparative advantages. Competitive advantage is shared among graduates in the same department, whereas the comparative advantage differs from one school to other schools. This research is focused on the ability of emotional and spiritual 
intelligence of educators to improve the quality of learning interaction, particularly in Parepare Public Secondary Schools[10].

\section{METHOD}

The research applied a mixed method, qualitative and quantitative approaches. This research was conducted in five different Public Secondary Schools in a Senior High School Level in Parepare City. The sampling was done using purposive sampling (direct appointment) and directly designated about $20 \%$ in each school. These are; 1) 24 teachers at Senior High SchoolI; 2) 16 teachers at Senior High School-II; 3) 15 teachers at Senior High School-III; and 4) 8 teachers at Senior High School-IV. Thus, the total participants are 77 teachers.

\section{Data Gathering}

The applied techniques to gather the data were actual observation, documentation, questionnaires, and oral interviews.

Data Analysis

The quantitative and qualitative data were analysized using descriptive analysis. The quantitative descriptive analysis was performed with frequency distribution statistics. The analysis was to reveal the states or characteristics of the sample data for a single research variable. According Yousdo and Arifin (1993) as Guilford intended that the frequency distribution was implemented if the largest value difference is minus the smallest value [11]:

Formula:

$\mathrm{i}=\mathrm{r} / \mathrm{k}$, i.e. $\mathrm{i}=$ interval width; $\mathrm{r}=$ distance of measurement; $\mathrm{k}=$ number of intervals

Descriptive quantitative analysis was performed using descriptive statistical techniques, such as frequency distribution, graph, concentration size, and size of the spread. Therefore, the study outcomes could be concluded with a relatively more precision. Trihendradi (2005) underlined that another applicable analysis was to use an SPSS version 12.00 software. A multiple linear regression analysis connected between variables by removing the results of data processing on the degree of closeness on the said relationship. Regression linear was intended to determine the linear relationship between independent and dependent variables. The value of the correlation or the relationship between emotional and spiritual intelligence variables as well as learning interactions could be based on Young's opinions as follows:

1. $0.7-1.00$, both positive and negative, shows a high degree of relationship.

2. $0.4-0.7$, both positive and negative, indicates a substantial degree relationship

3. $0.2-0.4$, both positive and negative, shows a low degree relationship.

4. $<0.2$, both positive and negative indicates that the relationship is negligible.
Descriptive qualitative analysis was formulated based on the data gathering outcomes in the form of words or sentences and informations. In-depth information digging was carried out in order to be able to answer the relationship between the ability of EQ and SQ in the learning interaction with the convincing level of validity and reliability data.

\section{RESULT}

\section{The Emotional Intelligence of a Teacher}

The teacher intelligence level at Senior High School in Parepare City, corresponding with the results of descriptive analysis on the frequency scale showed the mean was 60.51 ; median was 60 ; standard deviation was 6,654; variance was 44.280; skwenes was 0,442 ; kurtosis was 0.151 ; range was 32 ; minimum value was 48 ; and the maximum value was 80 . The distributions of tabulation of emotional intelligence level of public senior high schools in Parepare City were as follows Table 1.

Table 1: The Emotional Intelligence Category

\begin{tabular}{llll}
\hline & $\mathrm{F}$ & $\%$ & $\%$ Valid \\
\hline$<52$ (very low) & 6 & 7.8 & 7.8 \\
\hline 52-57 (low) & 18 & 23.4 & 23.4 \\
\hline 58-61 (moderate) & 21 & 27.3 & 27.3 \\
\hline 62-72 (advance) & 28 & 36.4 & 36.4 \\
\hline$>72$ (very high) & 4 & 5.2 & 5.2 \\
\hline \multicolumn{1}{c}{ Total } & 77 & 100.0 & 100.0 \\
\hline
\end{tabular}

Based on the data description in table 1 above, it could be concluded that the emotional intelligence level of teachers was categorized 'high' with a cumulative of $36.4 \%$ with a frequency of 28 respondents. In addition, the data showed the 'moderate' category of $27.3 \%$ with 21 respondents. The results of the data analysis were showing that the emotional intelligence level was categorized as high. The proficiency and emotional intelligence of the teachers would always build a sense of empathy to the learners, be able to understand and control their self-emotion, and draw closer relation with their learners. And, they were able to motivate themselves and learners, and so on.

\section{The Spiritual Intelligence of a Teacher}

Based on the descriptive analysis outcomes, the spiritual intelligence of the teachers on a frequency scale showed a mean of 56.83 ; median of 58 ; standard deviation of 11,517 ; variance of 132,642 ; skewnes of 1,190 ; kurtosis of 3,619 ; range of 70 ; minimum value of 10 ; and the maximum value of 80 . The distribution of tabulation of the spiritual intelligence level of Senior High School teachers in Parepare City were:

From table 2 above, it could be concluded that the spiritual intelligence level of the teachers was categorized 'high' with a cumulative of $39.0 \%$ with a frequency of 30 participants. Thus, the data indicated the 'low' category of $37.7 \%$ with 29 respondents. The medium category was $10.4 \%$ with 8 respondents. The 
result of the data analysis was the spiritual intelligence level of the teachers at Public Senior High Schools in Parepare City was categorized as "high" and also "low" category at the same time. The high spiritual intelligence describes the ability of the teachers incorporating spiritual values into the presentation of teaching materials.

Table 2: The Spiritual Intelligence Category

\begin{tabular}{llll}
\hline$<31$ (very low) & $\frac{\mathrm{F}}{3}$ & $\frac{\%}{3.9}$ & $\frac{\% \text { Valid }}{3.9}$ \\
\hline $31-56$ (low) & 29 & 37.7 & 37.7 \\
\hline $55-58$ (moderate) & 8 & 10.4 & 10.4 \\
\hline $59-70$ (advance) & 30 & 39.0 & 39.0 \\
\hline$>71$ (very high) & 7 & 9.1 & 9.0 \\
\hline Total & 77 & 100.0 & 100.0 \\
\hline
\end{tabular}

\section{The Quality of Learning Process}

The quality of the learning process was the occurrence of effective and efficient educational interaction and run according to a lesson plan. All learning tools work optimally and varied methods and learning strategies were applied in order to create more conducive learning atmosphere in the classroom. A spiritual intelligence of the teachers on a frequency scale was showing a mean of 74.05 ; median of 74.00 ; standard deviation of 3,387 ; variance of 11,471 ; skewnes of $-0,901$; kurtosis of 2.075 ; range of 20 ; minimum value of 61 ; and maximum value of 81 .

The data analysis outcomes from table 3 displayed the quality of learning process of cumulative category with 'cumulative' of $39 \%$ for 30 respondents, while the assessment of respondents categorized 'low' was around 22 respondents with cumulative of $28.6 \%$. The learning process quality was categorized as 'medium' in term of the teachers' ability in designing materials, learning management, the completeness of instructional infrastructure and the readiness of learners in learning.

Table 3: The Quality of Learning Category

\begin{tabular}{llll}
\hline & $\mathrm{F}$ & $\%$ & $\%$ Valid \\
\hline$<67$ (very low) & 4 & 5.2 & 5.2 \\
\hline $65-73$ (low) & 22 & 28.6 & 28.6 \\
\hline $74-76$ (moderate) & 30 & 39.0 & 39.0 \\
\hline $77-79$ (advance) & 19 & 24.7 & 24.7 \\
\hline$>79$ (very high) & 2 & 2.6 & 2.6 \\
\hline Total & 77 & 100.0 & 100.0 \\
\hline
\end{tabular}

In the infrared analysis, the emotional and spiritual intelligence variables were analyzed to the extent of their influence on the quality of the learning process. The variable of emotional intelligence and the quality of the learning process had a Pearson correlation value of 0.239 and a significance level of 0.18 . The value of Pearson correlation was 0.239 and was at the interval level of 0.2 $-0.4$

Also, the variable of spiritual intelligence and quality of the learning process has the value of Pearson correlation of 0.242 and significance level of 0.17 .
Pearson correlation value of 0.242 and is at the interval level 0.2 - 0.4 For more details see the level of correlation on each variable in table.

Affirming that the emotional intelligence was significantly affecting the improvement quality of the learning process at Senior High Schools in Parepare City. Emotional intelligence had the level of significance of 0.18 , and significance level of spiritual intelligence variables was 0.17 . The lowest variable of significance was the spiritual intelligence then new to the level of emotional intelligence.

Table 4: The Pearson Correlations ( $=77)$

\begin{tabular}{llll}
\hline & $\begin{array}{l}\text { Learning } \\
\text { Process }\end{array}$ & $\begin{array}{l}\text { Emotional } \\
\text { Intelligence }\end{array}$ & $\begin{array}{l}\text { Spiritual } \\
\text { Intelligence }\end{array}$ \\
\hline The Learning Pro & 1.00 & $-239^{* *}$ & $-242^{* *}$ \\
EI & & 1.00 & $384^{* *}$ \\
SI & & & 1.00 \\
\hline
\end{tabular}

\section{CONCLUSION}

The teachers level of emotional intelligence at Senior High School in Parepare City was $36.4 \%$ with frequencies about 28 participants, and the data were showing 'moderate' category of $27.3 \%$ with 21 respondents. Thus, the emotional intelligence level of the teachers was categorized 'high'. Then, the spiritual intelligence level of the teachers was categorized 'high' with a cumulative of $39.0 \%$, with a frequency of 30 respondents. On the other hands, the respondent's appreciation indicated a 'low' category of $37.7 \%$ with 29 participants.

The emotional intelligence with Pearson correlation resulted in 0.239 and was at the interval level $0.2-0.4$. It indicated that emotional intelligence variable had a "low" relation (influence) to the improvement quality of learning process. A spiritual intelligence had a Pearson correlation value of 0.242 and the interval level of 0.2 0.4 . This indicated that spiritual intelligence variables had a low relation influence to the improvement quality of the learning process.

\section{REFERENCES}

[1] N. Felicia, "Factors associated with cognitive development of primary school children in eastern Indonesia," ProQuest Diss. Theses, 2016.

[2] N. Felicia, "Factors associated with cognitive development of primary school children in eastern Indonesia.," Diss. Abstr. Int., 2017.

[3] I. F. Nur dan A. Ekasari, "Hubungan antara konsep diri dengan kecerdasan emosional pada remaja," J. Soul, 2008.

[4] N. Suwandewi, I. G. Ayu, dan M. Dewi, "Pengaruh kecerdasan emosional dan dukungan organizational terhadap organizational citizenship behavior," E-Jurnal Manaj. Unud, 2016.

[5] Fitriastuti, "Pengaruh Kecerdasan Emosional, Komitmen Organisasional Dan Organizational 
Citizenship Behavior Terhadap Kinerja Karyawan,” J. Din. Manaj., 2013.

[6] M. Habibulloh dan D. B. Maunah, "Kecerdasan Emosional Guru Dalam Membina Moralitas Peserta Didik," Muh. Habibulloh dan Binti Maunah, 2005.

[7] G. A. Sari, "Pengaruh kecerdasan spiritual, kecerdasan emosional, dan locus of control terhadap perilaku etis mahasiswa akuntansi (Studi Empiris Mahasiswa erguruan tinggi Negeri Kota Padang)," Univ. Negeri Padang, 2016.
[8] H. N. Akimas dan A. A. Bachri, "Pengaruh Kecerdasan Intelektual (Iq), Kecerdasan Emosional (Eq), Kecerdasan Spiritual (Sq) Terhadap Kinerja Pegawai Inspektorat Provinsi Kalimantan Selatan Hari," J. Wawasan Manaj., 2016.

[9] E. Nurdiyansyah, "Pengaruh Kecerdasan Spiritual , Kecerdasan Emosional , Dampak Terhadap Hasil Belajar Matematika Siswa," J. EST, 2017.

[10] Nurdin, "Pengaruh kecerdasan emosional terhadap penyesuaian sosial siswa di sekolah," $J$. Adm. Pendidik., 2009.

[11] J. P. Guilford dan R. B. Guilford, "An analysis of the factors in a typical test of introversionextroversion," J. Abnorm. Soc. Psychol., 1934. 